OPEN ACCESS

Edited by:

Lei Xi,

Virginia Commonwealth University,

United States

Reviewed by:

Andres Contreras,

Michigan State University,

United States

Aijuan Qu,

Capital Medical University, China

Shunchang Li,

Chengdu Sport University, China

*Correspondence:

Guicheng Wu

wuguic@hotmail.com

Chengwei Tang

shcacdmed@163.com

${ }^{\dagger}$ These authors have contributed equally to this work

Specialty section:

This article was submitted to Translational Pharmacology, a section of the journal

Frontiers in Pharmacology

Received: 11 May 2020 Accepted: 03 August 2020 Published: 14 August 2020

Citation:

Wu G, Liu Y, Feng W, An X, Lin W and

Tang C (2020) Hypoxia-Induced Adipose Lipolysis Requires Fibroblast Growth Factor 21.

Front. Pharmacol. 11:1279. doi: 10.3389/fphar.2020.01279

\section{Hypoxia-Induced Adipose Lipolysis Requires Fibroblast Growth Factor 21}

\author{
Guicheng $\mathrm{Wu}^{1,2^{*}}{ }^{\text {, }}$, Yanlong $\mathrm{Liu}^{3,4 t}$, Wenke Feng ${ }^{5}$, Xuan $\mathrm{An}^{2}$, Wenhui Lin ${ }^{6}$ \\ and Chengwei Tang ${ }^{1,7 *}$
}

\begin{abstract}
${ }^{1}$ Department of Gastroenterology, West China Hospital, Sichuan University, Chengdu, China, ${ }^{2}$ Department of Hepatology, Chongqing University Three Gorges Hospital, Chongqing, China, ${ }^{3}$ School of Mental Health, Wenzhou Medical University, Wenzhou, China, ${ }^{4}$ Zhuji Institute of Biomedicine, School of Pharmaceutical Sciences, Wenzhou Medical University, Shaoxing, China, ${ }^{5}$ Alcohol Research Center, University of Louisville School of Medicine, Louisville, KY, United States, ${ }^{6}$ Department of Cardiology, Affiliated Wenling Hospital of Wenzhou Medical University, Wenling, China, ${ }^{7}$ Laboratory of Gastroenterology \& Hepatology, State Key Laboratory of Biotherapy, Chengdu, China
\end{abstract}

Fibroblast growth factor 21 (FGF21) is a recently discovered hepatokine that regulates lipid and glucose metabolism and is upregulated in response to numerous physiological and pathological stimuli. Herein, we demonstrate that both physical and chemical hypoxia increase the systemic and hepatic expression of FGF21 in mice; by contrast, hypoxia induces a reduction of FGF21 expression in hepatocytes, indicating that hypoxia-induced FGF21 expression is differentially regulated in intact animals and in hepatocytes. Furthermore, we demonstrate that hypoxia treatment increases hormone-sensitive lipase-mediated adipose tissue lipolysis in mice, which is reduced in Fgf21 knockout mice, thereby implying that FGF21 plays a critical role in hypoxia-related adipose lipolysis. Adipose tissue lipolysis causes an increase in the amount of circulating free fatty acids, which leads to the activation of peroxisome proliferators-activated receptor alpha and an increased expression of FGF21 in hepatocytes. We further show that hypoxia-induced elevation of reactive oxygen species, but not the hypoxia-inducible factor, is responsible for the lipolysis and FGF21 expression. In conclusion, our data clearly demonstrate that FGF21 plays a critical role in hypoxia-induced adipose lipolysis, which induces hepatic expression of FGF21. Clarification of hypoxia-regulated FGF21 regulation will enhance our understanding of the pathophysiology of hypoxia-related diseases, such as sleep disorders and metabolic diseases.

Keywords: fibroblast growth factor 21, free fatty acid, lipolysis, hormone sensitive lipase, hypoxia-inducible factor

\section{INTRODUCTION}

Adipose tissue functions as the major fat storage site in the form of triglycerides (TGs). Adipose tissue synthesizes TG when energy intake exceeds energy output, while during fasting or in response to stress, adipose tissue mobilizes free fatty acids (FFAs) and glycerol (lipolysis), providing other tissues with metabolites and energy substrates. While lipolysis is a physiological response to metabolic changes, excess lipolysis may lead to increased circulating FFA levels, which is a risk factor for a variety of metabolic diseases. Previous studies have shown that adipose tissue lipolysis is associated with tissue hypoxia (Mahat et al., 2016), which is a pathophysiological state existing in 
many disease conditions (Famulla et al., 2012; Plihalova et al., 2016; Zhang et al., 2017). At molecular level, lipolysis and hypoxia have been linked to fibroblast growth factor 21 (FGF21), respectively (Arner et al., 2008; Cai et al., 2019).

FGF21 is a member of the FGF superfamily and is a potential metabolic regulator (Degirolamo et al., 2016; Kliewer and Mangelsdorf, 2019; Lewis et al., 2019). Generally, FGFs require heparin to promote binding to the tyrosine kinase FGF receptors (FGFRs) and act in a paracrine or autocrine fashion (Beenken and Mohammadi, 2009). FGF21 does not possess a heparinbinding domain and is therefore secreted into the circulation, where it exerts its functions through the activation of a unique dual receptor system consisting of FGFRs and a co-receptor, $\beta$ klotho (Ding et al., 2012); in this way, it can function in an endocrine fashion.

Circulating FGF21 levels have been found to be elevated in patients and experimental animals with various metabolic conditions, such as obesity (Dushay et al., 2010), non-alcoholic fatty liver disease (Kim et al., 2015), and type 2 diabetes (Barb et al., 2019). Besides, previous studies have demonstrated that there was a association between hypoxia and FGF21 regulation in many diseases such as type 2 diabetes with early renal injury (Yu et al., 2019), pulmonary hypertension (Cai et al., 2019), and cerebral disease (Wang et al., 2019). Hypoxic conditions increase the circulating concentrations of FFAs, which are produced from adipose tissue by increased lipolysis (Yin et al., 2009). The FFAs, in turn, activate peroxisome proliferators-activated receptor alpha $(P P A R \alpha)$ and increase FGF21 expression in the liver, which is the main organ for circulating FGF21 production in humans and rodents (Fon Tacer et al., 2010). FGF21 has been shown to play a role in adipose tissue lipolysis, which increases the circulating FFAs that contribute to various pathologic conditions including hepatic steatosis. However, whether FGF21 plays a role in hypoxia-induced adipose tissue lipolysis is, as yet, unknown.

In the present study, we found that hypoxia increased systemic and hepatic expression of FGF21 as well as hormonesensitive lipase-mediated adipose tissue lipolysis in mice. This hypoxia-induced lipolysis is attenuated in the Fgf 21 knockout (KO) mice. Furthermore, we found that the increase in FGF21 expression is not due to the activation of hypoxia-inducible factor (HIF) by hypoxia in hepatocytes, but through hypoxiainduced adipose tissue lipolysis leading to the mobilization of FFAs and the activation PPAR $\alpha$ in the liver and hypoxia-induced oxidative stress.

\section{MATERIAL AND METHODS}

\section{Cell Culture}

HepG2 and H4IIE cells were purchased from the American Type Culture Collection (ATCC, Rockville, MD). Hif- $1 \alpha$ and Hif- $2 \alpha$ knockdown HepG2 cells were kindly provided by Dr. Bernhard Brune (Menrad et al., 2010). The cells were cultured in Dulbecco's Modified Eagle Medium (DMEM), supplemented with $100 \mathrm{U} / \mathrm{ml}$ of penicillin, $100 \mu \mathrm{g} / \mathrm{ml}$ of streptomycin, and
$10 \%$ fetal bovine serum (FBS), at $37^{\circ} \mathrm{C}$ in a humidified $5 \% \mathrm{CO}_{2}$ environment. The culture media were changed every two days. The cells were subcultured after partial digestion with $0.25 \%$ trypsin-EDTA. In some experiments, HepG2 cells were treated with $1 \% \mathrm{O}_{2}$ or chemical hypoxia inducer cobalt chloride $\left(\mathrm{CoCl}_{2}\right.$, $0.01 \mathrm{mg} / \mu \mathrm{l})$ for $24 \mathrm{~h}$. The PPAR $\alpha$ antagonist, GW6471 (100 $\mathrm{nmol} / \mathrm{L}$ ), was used to determine whether FGF21 expression is mediated by PPAR $\alpha$. HIF-1 $\alpha$ inhibitor, 2-Methoxyestradiol (2ME2) $(100 \mu \mathrm{m})$, was used for $12 \mathrm{~h}$ to determine whether the effects of hypoxia on FGF-21 are HIF regulated.

\section{Animal Studies}

Male C57BL/6 mice were purchased from the Experimental Animal Center of Chongqing Medical University (Chongqing, China). Fgf21 KO mice were kindly provided by Dr. Steve Kliewer (Potthoff et al., 2009). Animals were maintained under 12:12 h light:dark cycle conditions.

For $\mathrm{CoCl}_{2}$ treatment: 8-10-week old mice were treated with $\mathrm{CoCl}_{2} 6 \mathrm{H}_{2} \mathrm{O}(60 \mathrm{mg} / \mathrm{kg}$, IP, Sigma) and fasted for $18 \mathrm{~h}$ to test. Experiment 1: Male C57BL/6 mice were divided randomly into three groups (Control, $\mathrm{CoCl}_{2}, \mathrm{CoCl}_{2}+\mathrm{NAC}$ ). Experiment 2: Male wildtype (WT) and $\mathrm{KO}$ mice were divided randomly into four groups (WT, WT $+\mathrm{CoCl}_{2}, \mathrm{KO}, \mathrm{KO}+\mathrm{CoCl}_{2}$ ). Each group had 7 mice.

For intermittent hypoxia ( $\mathrm{IH}$ ) treatment: The murine model of IH exposure during sleep has been established and extensively utilized in the study of sleep apnea-associated morbidities. In this study, 8-10-week male C57BL/6 mice for exposure were divided into in two groups: an IH group and an intermittent air (IA) control group with 7 mice in each group. The $\mathrm{IH}$ paradigm consisted of $20.9 \% \mathrm{O}_{2} / 8 \% \mathrm{O}_{2} \mathrm{~F}_{\mathrm{I}} \mathrm{O}_{2}$ alternate cycles ( 30 episodes $/ \mathrm{h}$ ) with $20 \mathrm{~s}$ at the nadir $\mathrm{F}_{\mathrm{I}} \mathrm{O}_{2}$ for $12 \mathrm{~h}$ a day during daylight. Pulse oxyhemoglobin saturation $\left(\mathrm{SpO}_{2}\right)$ changed in a recurrent manner with the nadir hemoglobin oxygen saturations mainly remaining in the range $60-70 \%$ to mimic hypoxia/reoxygenation events occurring in patients with moderate to severe obstructive sleep apnea. The IH exposure continued for eight weeks.

The humidity, ambient $\mathrm{CO}_{2}$, and temperature $\left(22 \pm 1^{\circ} \mathrm{C}\right)$ in the chambers were regularly monitored and maintained during the treatment. After IH/IA exposure, the mice were transferred to room air until they were humanely sacrificed for tissue collection. At the end of the experiment, the mice were anesthetized with Avertin $(250 \mathrm{mg} / \mathrm{kg})$, and tissue samples were collected for assays. Mice were treated according to the protocols reviewed and approved by the Institutional Animal Care and Use Committee of Chongqing University Three Gorges Hospital [2017(021)].

\section{Differentiation of 3T3-L1 Fibroblasts Into Adipocytes}

3T3-L1 fibroblasts (ATCC, Rockville, MD) were cultured in DMEM that contained high glucose $(4.5 \mathrm{~g} / \mathrm{L})$, glutamine $(584 \mathrm{mg} / \mathrm{L})$, and sodium pyruvate $(110 \mathrm{mg} / \mathrm{L})$ supplemented with $10 \%$ newborn calf serum (Gibco/Invitrogen; Carlsbad, CA, USA) and maintained at $37^{\circ} \mathrm{C}$ in $5 \% \mathrm{CO}_{2}$. In accordance with a standard protocol, 3T3-L1 fibroblasts were differentiated into adipocytes. Briefly, differentiation 
was induced two days after confluency by the addition of DMEM containing 10\% FBS and dexamethasone ( $1 \mu \mathrm{mol} / \mathrm{L}$, Sigma-Aldrich; St. Louis, MO, USA), 3-isobutyl-1-methylxanthine (0.5 mmol/L, Sigma-Aldrich), and insulin (100 nmol/L) (Gibco/Invitrogen) for two days. The cells were then further incubated with DMEM supplemented with insulin for another two days. Fully differentiated adipocytes were maintained in DMEM at $37^{\circ} \mathrm{C}$ in a humidified atmosphere containing $5 \% \mathrm{CO}_{2}$, and they were used 914 days after differentiation was initiated.

\section{Isolation and Culture of Primary Adipocytes}

Male C57BL/6 mice were used to obtain primary adipocytes. Briefly, the mice were anesthetized and euthanized by cervical dislocation. The epididymal fat pads were harvested, washed in phosphate-buffered saline (PBS, $\mathrm{pH} 7.4$ ) at room temperature, and minced thoroughly $(2-3 \mathrm{~mm})$ in collagenase solution $(0.2$ $\mathrm{mg} / \mathrm{ml}$ of collagenase $\mathrm{A}, 4 \mathrm{ml} / \mathrm{g}$ of adipose tissue). This mixture was then incubated at $37^{\circ} \mathrm{C}$ and shaken at $120 \mathrm{rpm}$ for $30 \mathrm{~min}$. After digestion, the mixture was filtered through a $250-\mu \mathrm{m}$ gauze mesh into a 50-ml conical polypropylene tube; it was then allowed to stand for 2-3 min. The floating layer of adipocytes was washed three times and incubated at $37^{\circ} \mathrm{C}$ in DMEM containing $1 \%$ bovine serum albumin.

\section{RNA Interference}

siRNAs that target human HIF- $1 \alpha$ and a negative mismatched control were designed and synthesized by Ambion, Inc. (Austin, TX). The siRNA sequences for HIF-1 $\alpha$ were as follows: sense, GCUUAUUGAGAAUGAGGAGTT; antisense, CUCCUCAUU CUCAAUAAGCTC. After the monolayer cultures attained 50\% confluence, the cells were transfected with $100 \mathrm{nmol} / \mathrm{L}$ of HIF-1 $\alpha$ -targeted or negative-mismatched siRNA using Lipofectamine 2000 (Invitrogen) in accordance with the manufacturer's instructions. Antibiotics were added to the medium $24 \mathrm{~h}$ after transfection, and the cells were used for the experimental procedures $48 \mathrm{~h}$ after transfection.

\section{Nuclear Extract Preparation}

The cells were washed once on a dish with ice-cold PBS. Ice-cold buffer $(10 \mathrm{mmol} / \mathrm{L}$ of Tris- $\mathrm{HCl}, \mathrm{pH} 7.8,1.5 \mathrm{mmol} / \mathrm{L}$ of $\mathrm{MgCl} 2$, and $10 \mathrm{mmol} / \mathrm{L}$ of $\mathrm{KCl}$ ) containing freshly added $0.4 \mathrm{mmol} / \mathrm{L}$ of phenylmethylsulfonyl fluoride (PMSF), $0.5 \mathrm{mmol} / \mathrm{L}$ of dithiothreitol (DTT), and $1 \%$ protease inhibitor cocktail (Sigma-Aldrich) was overlaid on the cells in the dish and incubated for $10 \mathrm{~min}$. Next, the cells were harvested by scraping with a rubber cell policeman and lysed by Dounce homogenization. The nuclei were pelleted by centrifugation and then resuspended in ice-cold buffer $(20 \mathrm{mmol} / \mathrm{L}$ of Tris- $\mathrm{HCl}, \mathrm{pH}$ $7.8,420 \mathrm{mmol} / \mathrm{L}$ of $\mathrm{KCl}, 1.5 \mathrm{mmol} / \mathrm{L}$ of $\mathrm{MgCl}_{2}$, and $20 \%$ glycerol) containing freshly added $0.4 \mathrm{mmol} / \mathrm{L}$ of PMSF, $0.5 \mathrm{mmol} / \mathrm{L}$ of DTT, $1 \%$ protease inhibitor cocktail, and $1 \mathrm{mmol} / \mathrm{L}$ of $\mathrm{Na}_{3} \mathrm{VO}_{4}$, and incubated for $30 \mathrm{~min}$ on ice with occasional tapping. The extracts were clarified by centrifugation at $12,000 \mathrm{~g}$ for $15 \mathrm{~min}$ at $4^{\circ} \mathrm{C}$, placed in aliquots, and then stored at $-80^{\circ} \mathrm{C}$.

\section{Reactive Oxygen Species (ROS) Determination by Fluorescence Microscopy}

The superoxide content in the HepG2 cells was examined by dihydroethidium (DHE, Molecular Probes, Eugene, OR) fluorescence microscopy. Nonfluorescent DHE is oxidized by superoxide, yielding a red fluorescent product, ethidium, that binds to nucleic acids, staining the nucleus a bright fluorescent red. Cryostat sections of the HepG2 cell chamber slides were incubated with $5 \mu \mathrm{mo} / \mathrm{L}$ of DHE for $30 \mathrm{~min}$ at $37^{\circ} \mathrm{C}$ in the dark. The ROS-catalyzed ethidium red fluorescence was examined using fluorescence microscopy.

\section{Quantitative Real-Time PCR}

The mRNA expression was assessed by real-time PCR (RTPCR). In brief, the total RNA (either from the frozen tissues or the cultured cells) was isolated with Trizol in accordance with the manufacturer's protocol (Invitrogen) and reverse-transcribed using a GenAmp RNA PCR kit (Applied Biosystems, Foster City, CA). The cDNA was amplified in 96-well reaction plates with a SYBR green PCR Master Mix (Applied Biosystems) on an ABI 7500 RT-PCR thermocycler. Table 1 lists the forward and reverse primers. The relative quantities of the target transcripts were calculated from the duplicate samples after normalization to a housekeeping gene, $\beta$-actin. After PCR amplification to confirm the specificity of the primers, dissociation curve analysis was performed. The relative mRNA expression was calculated using the $2^{-\triangle \triangle \mathrm{CT}}$ method.

\section{Western Blot Analysis}

Hepatic and adipose tissues were homogenized, and the HepG2 cells were lysed on ice for $30 \mathrm{~min}$ in RIPA buffer $(50 \mathrm{mmol} / \mathrm{L}$ of Tris. $\mathrm{HCl}, \mathrm{pH} 7.4,150 \mathrm{mmol} / \mathrm{L}$ of $\mathrm{NaCl}, 2 \mathrm{mmol} / \mathrm{L}$ of EDTA, 4 $\mathrm{mmol} / \mathrm{L}$ of $\mathrm{Na}_{3} \mathrm{VO}_{4}, 40 \mathrm{mmol} / \mathrm{L}$ of $\mathrm{NaF}, 1 \%$ Triton $\mathrm{X}-100,1$ $\mathrm{mmol} / \mathrm{L}$ PMSF, and $1 \%$ protease inhibitor cocktail) and centrifuged at $14,000 \mathrm{~g}$ for $10 \mathrm{~min}$. The supernatants were

TABLE 1 | Primer Sequence for RT-PCR.

\begin{tabular}{|c|c|c|c|}
\hline \multirow{2}{*}{$\begin{array}{l}\text { Gene } \\
\text { Glut1 }\end{array}$} & \multirow{2}{*}{$\begin{array}{l}\text { Source } \\
\text { Human }\end{array}$} & \multicolumn{2}{|c|}{ Sequences (Forward/Reverse 5'-3') } \\
\hline & & CATCAATGCCCCCCAGAA & AAGCGGCCCAGGATCAG \\
\hline FGF21 & Human & ACCTGGAGATCAGGGAGGAT & GCACAGGAACCTGGATGTCT \\
\hline $\mathrm{HIF}-1 \alpha$ & Human & CCCAATGGATGATGACTTCC & TGGGTAGGAGATGGAGATGC \\
\hline$\beta$-actin & Human & GAGACCTTCAACACCCC & ATAGCTCTTCTCCAGGGAGG \\
\hline FGF21 & Mouse & CCTCTAGGTITCTIGCCAACAG & AAGCTGCAGGCCTCAGGAT \\
\hline$\beta$-actin & Mouse & GGCTGTATTCCCCTCCATCG & CCAGTTGGTAACAATGCCATGT \\
\hline
\end{tabular}


collected. Aliquots containing $30 \mu \mathrm{g}$ of protein were loaded onto 4-15\% SDS-polyacrylamide gels. After electrophoresis, the proteins were transferred onto a polyvinylidene fluoride membrane. The membrane was probed with antibody against HIF-1 $\alpha$ (BD, Sparks, MD), hormone-sensitive lipase (HSL) and p-HSL (Cell signaling, Danvers, MA), FGF21 (Abcam, San Francisco, CA), adipose triglyceride lipase (ATGL), protein kinase A (PKA) substrate (Cell Signaling technologies), and $\beta$ actin (Santa Cruz Biotechnologies, Santa Cruz, CA). Then, the membrane was processed with horseradish peroxidase-conjugated IgG. An enhanced chemiluminescence detection system (GE Healthcare, Piscataway, NJ) was used to envisage the protein bands, which were then quantified by densitometry analysis.

\section{Biochemical Assays}

The FGF21 levels in the plasma and the HepG2 cell media were measured with an FGF21 ELISA kit (Biovendor, Modrice, Czech Republic) in accordance with the manufacturer's instructions. The FFAs in the plasma and the 3T3-L1 adipocytes were measured using an NEFA C kit (Wako Chemicals, Richmond, VA). The glycerol in the plasma and the 3T3-L1 adipocytes culture supernatants were measured using a Glycerol Colorimetric Assay Kit (Cayman Chemical, Ann Arbor, MI). The plasma adrenaline and noradrenaline levels were measured using an ELISA kit from Labor Diagnostika Nord (Nordhorn, Germany). Cyclic AMP (cAMP) levels were measured in epididymal white adipose tissue (eWAT) using cAMP direct immunoassay kit (Abcam, Cambridge, MA) according to the manufacturer's protocol.

\section{Statistical Analysis}

Data are expressed as means \pm SEM. Statistical analysis was performed using GraphPad Prism 8 (GraphPad Software Inc., San Diego, CA, USA). Statistical comparisons were made using two -way analysis of variance (ANOVA) with Bonferroni's post hoc test or one-way ANOVA with Tukey's post hoc test or Student $t$-test where it was appropriate. Differences were considered to be significant at $P<0.05$. Statistical methods and corresponding $p$ values for data shown in each panel were included in figure legends.

\section{RESULTS}

\section{Hypoxia Increases FGF21 Expression in Mice}

IH treatment caused a significant $(\mathrm{p}<0.05)$ increase in the circulating FGF21 level (Figure 1A), and hepatic Fgf21 mRNA level (Figure 1B). Chemical hypoxia treatment increased the circulating FGF21 levels, the hepatic Fgf21 mRNA and protein expression by eight folds, six folds and two folds, respectively, compared with the control mice (Figures 1C-F). However, chemical hypoxia treatment did not change the Fgf21 mRNA expression in the WAT (Figure 1G).
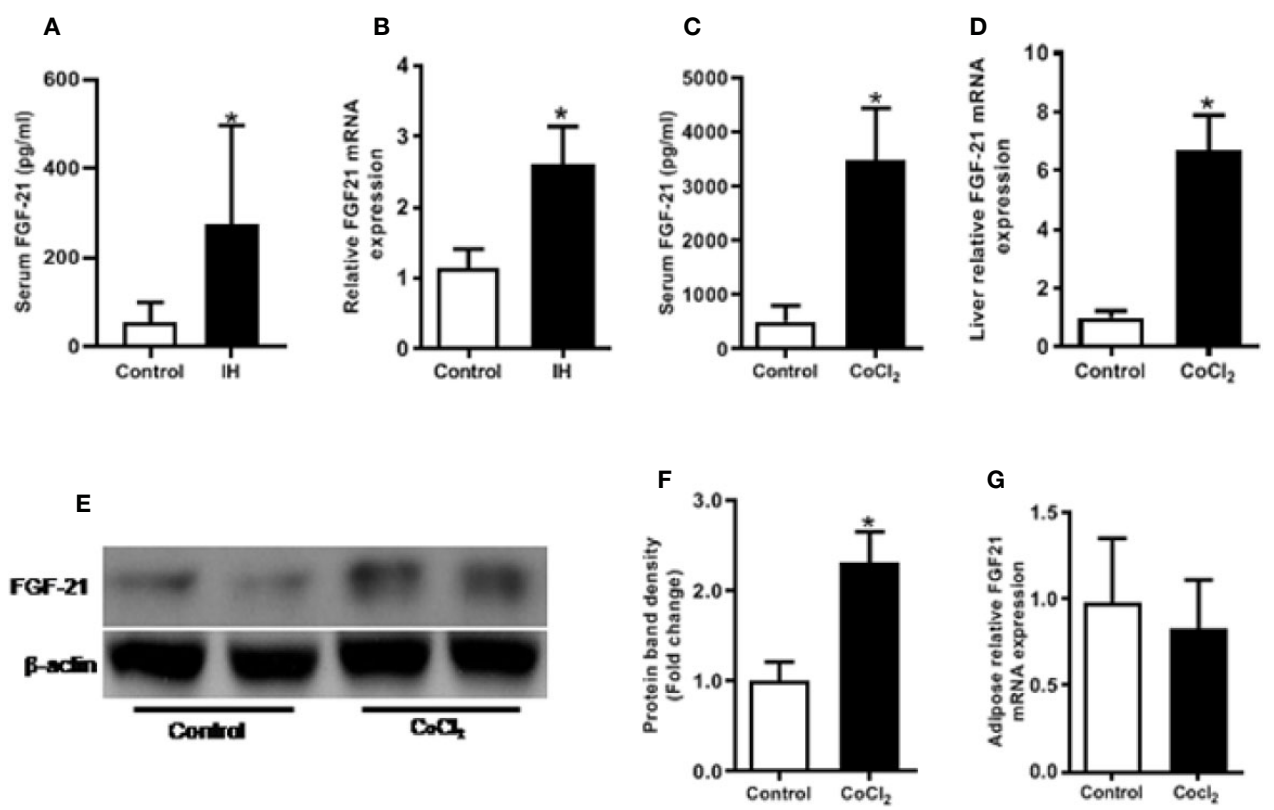

FIGURE 1 | Hypoxia increases FGF21 expression in mice. Control vs IH (intermittent hypoxia), Male C57BL/6 mice were divided into two groups and exposed for eight weeks to either intermittent hypoxia or intermittent air (control group). The serum FGF21 level was measured by ELISA in IH (A). Hepatic Fgf21 mRNA expression was measured by RT-PCR (B). Control vs $\mathrm{CoCl}_{2}$, The mice were also exposed to the chemical hypoxia mimic, $\mathrm{CoCl}_{2}$, and fasted for $18 \mathrm{~h}$. The serum FGF21 level was measured by ELISA (C). Liver Fgf21 mRNA (D) and protein (E, F) expression were measured by RT-PCR and Western blot, respectively. WAT Fgf21 mRNA (G) was measured by RT-PCR. *P $<0.05$. 


\section{Hypoxia-Induced Change in FGF21 Expression Is Not Mediated by HIF}

The immediate cellular response to hypoxia is the accumulation of the HIF- $\alpha$ protein. As shown in Figure 2A, both physical and chemical hypoxia induced a considerable elevation in HIF$1 \alpha$ protein levels. Furthermore, we examined the expression of GLUT-1, a well-known HIF-1 $\alpha$ transcription target, in response to the hypoxia treatment. As expected, hypoxia significantly increased Glut-1 mRNA expression in the HepG2 cells (Figure 2D). However, unlike the in vivo study, hypoxia treatment did not increase, rather decreased the cellular Fgf21 mRNA expression and protein secretion in the HepG2 cells (Figures 2E, F). These results suggest that FGF21 expression is differentially regulated in hepatocytes and in animal.

We treated the HepG2 cells with 2-ME2 or Hif-1 $\alpha$ specific siRNA to determine whether the change in FGF21 expression was mediated by the HIF protein level. Both of these treatments decreased the nuclear HIF-1 $\alpha$ protein levels (Figure 2B). However, reducing HIF- $1 \alpha$ did not affect the $\mathrm{CoCl}_{2}$-induced reduction of Fgf21 mRNA expression (Figure 2G). We further investigated the correlation between FGF21 expression and HIF levels using HepG2-derived stable cell lines, in which the Hif- $1 \alpha$ $(\operatorname{sh} 1 \alpha)$ or Hif- $2 \alpha(\operatorname{sh} 2 \alpha)$ was deleted, respectively. $\mathrm{CoCl}_{2}$ treatment did not increase the HIF- $1 \alpha$ in HepG2 cells, but significantly increased the HIF-2 $\alpha$ expression when the Hif- $1 \alpha$ was genetically deleted (Figure 2C). In a similar fashion, deletion of the Hif- $2 \alpha$ resulted in insensitizing of the HIF- $2 \alpha$ protein to $\mathrm{CoCl}_{2}$ treatment, but significantly increased the HIF-1 $\alpha$ protein (Figure 2C). Chemical hypoxia did not change the FGF21 expression in either Hif-1 $\alpha$ - or Hif- $2 \alpha$-deficient cell lines compared with the control (Figure $\mathbf{2 H}$ ). In summary, $\mathrm{CoCl}_{2}$ induced reduction in FGF21 expression in hepatocytes is independent of the HIF- $\alpha$ protein level.
A

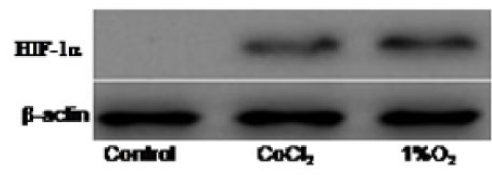

C
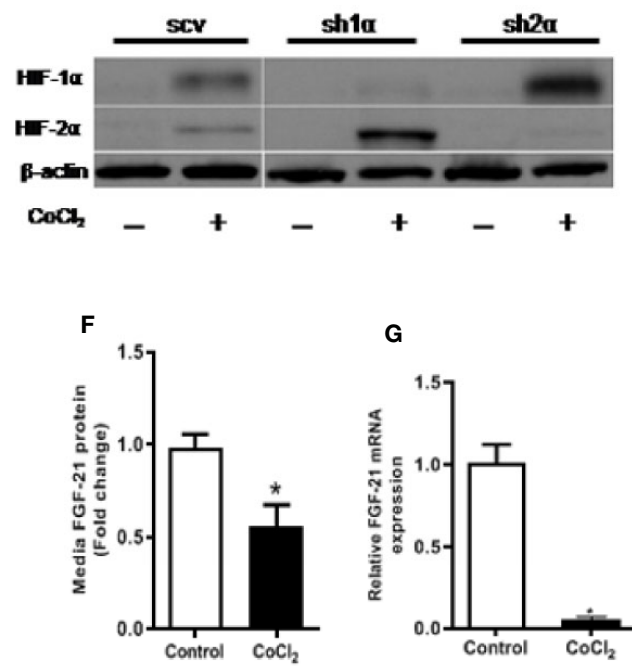

G

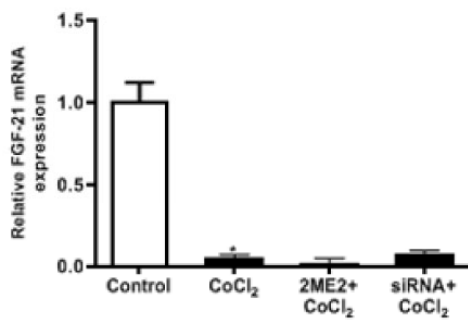

B

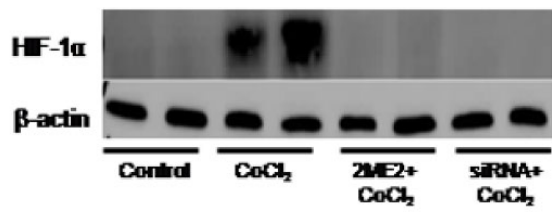

D

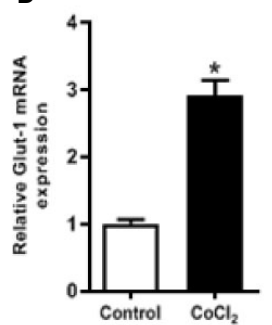

H

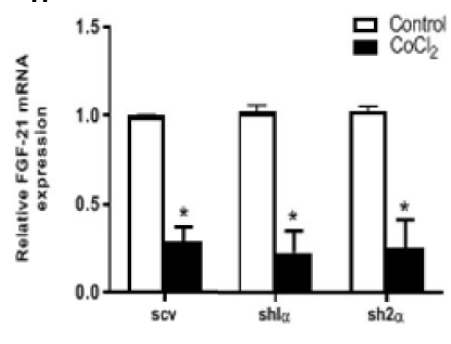

FIGURE 2 | Hypoxia-induced change in FGF21 expression is not mediated by HIF in HepG2 cells. HepG2 cells were treated with $\mathrm{CoCl}_{2}$ or exposed to $1 \% \mathrm{O}_{2}$ in the absence of serum for $18 \mathrm{~h}$. HIF-1 $\alpha$ protein expressions were determined by Western blot (A). Expression of HIF-1 $\alpha$ and HIF-2 $\alpha$ protein were measured by Western blot (C). Glut-1 mRNA levels were determined by RT-PCR (D). Cellular Fgf21 mRNA (E) and secreted protein in the median (F) were measured by RT-PCR and ELISA, respectively. HepG2 cells were treated with the HIF-1 $\alpha$ inhibitor, 2ME2 (100 $\mu \mathrm{M})$, for $12 \mathrm{~h}$ or transfected with HIF-1 $\alpha$ siRNA for $48 \mathrm{~h}$, respectively, followed by $\mathrm{CoCl}_{2}$ treatment for $18 \mathrm{~h}$. Expressions of HIF-1 $\alpha$ protein (B) and Fgf21 mRNA (G) were measured. WT HepG2 (scv), Hif-1 $\alpha$ KO (sh1 $\alpha$ ), and Hif-2 $\alpha$ KO (sh2 $\alpha$ ) HepG2 cells were exposed to $\mathrm{CoCl}_{2}$ in the absence of serum for $18 \mathrm{~h}$. Fgf21 mRNA expression was measured by RT-PCR (H). ${ }^{*} \mathrm{P}<0.05$. 


\section{The Hypoxia-Induced FGF21 Down- Regulation in HepG2 Cells and Up- Regulation in Mice Are Dependent on Oxidative Stress}

Previous studies have shown that ROS generation is induced by hypoxia (Siques et al., 2018). A potent antioxidant, NAC, together with $\mathrm{CoCl}_{2}$, was used to treat the HepG2 cells to determine whether the reduction of FGF21 expression in the HepG2 cells was due to $\mathrm{CoCl}_{2}$-induced oxidative stress. $\mathrm{CoCl}_{2}$ treatment induced a significant increase in the production of superoxide, which was evaluated by DHE staining. Also, administration of NAC significantly inhibited the $\mathrm{CoCl}_{2}$ induced ROS accumulation in HepG2 cells (Figure 3A). It is important to note that the $\mathrm{CoCl}_{2}$-induced decrease of cellular Fgf21 mRNA was evidently reduced by the NAC treatment (Figure 3B). Similarly, FGF21 secretion was also restored (Figure 3C). These results suggest that alteration of FGF21 expression in hepatocytes by hypoxia is inhibited by hypoxiainduced oxidative stress.

In the similar way, the mice were treated with $\mathrm{CoCl}_{2}$ in the presence of NAC to determine whether the increased
FGF21 expression was due to hypoxia-induced oxidative stress. Hypoxia-increased plasma FFA and glycerol were decreased by NAC treatment (Figures 3D, E), indicating that hypoxiainduced oxidative stress is probably the main cause of adipose tissue lipolysis. It is important to note that chemical hypoxiainduced elevation of FGF21 protein in the plasma and mRNA expression in the liver were inhibited by NAC treatment (Figures 3F, G), suggesting that the increase of FGF21 expression in the plasma and liver of hypoxia-treated mice is regulated by oxidative stress.

\section{Hypoxia Induces Adipose Lipolysis}

Adipose tissue lipolysis-released FFAs are ligands of PPAR $\alpha$, which is a major transcription factor that regulates the expression of $\mathrm{Fg} 21$ in the liver. To investigate whether $\mathrm{CoCl}_{2}$-induced FGF21 upregulation in mice is mediated by the increase of adipose tissue lipolysis, we measured the plasma FFA and glycerol levels. $\mathrm{CoCl}_{2}$ treatment increased plasma FFA level by two folds, and the glycerol level by one and a half folds (Figures 4A, B); indicating an increase in lipolysis under hypoxic conditions. Additionally, $\mathrm{CoCl}_{2}$ treatment significantly reduced mouse eWAT weight $(0.35 \pm 0.01 \mathrm{~g}$ vs. $0.49 \pm$

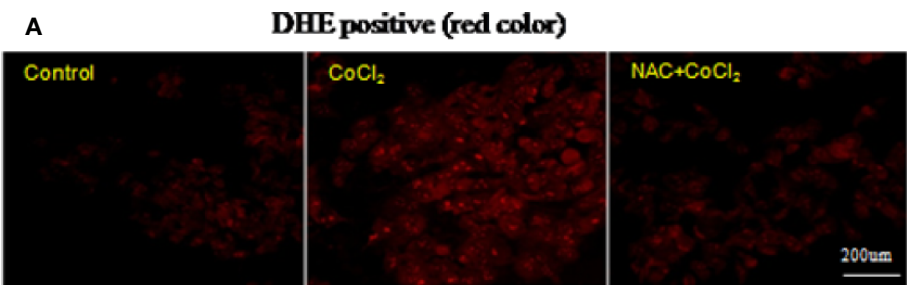

B

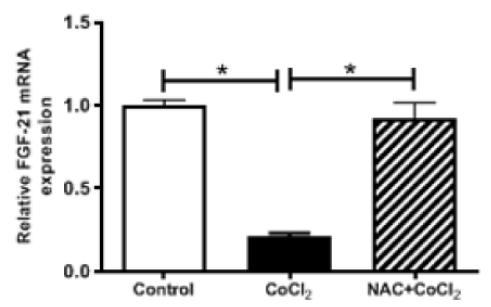

E

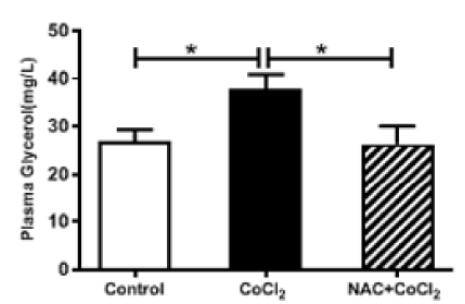

C

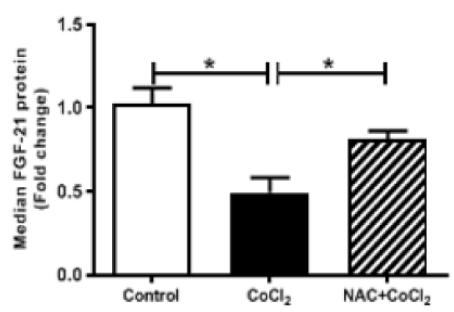

F

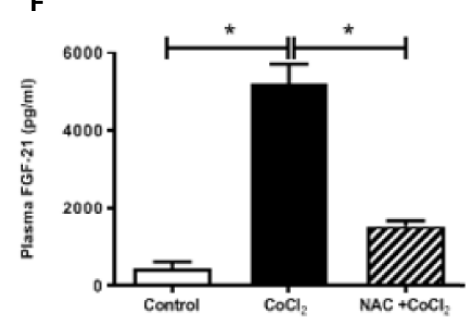

D

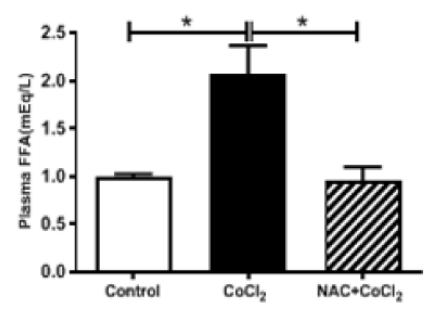

G

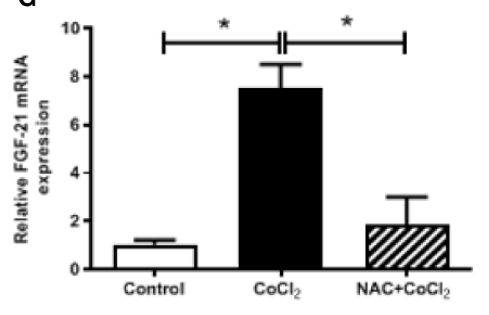

FIGURE 3 | The hypoxia-induced FGF21 down-regulation in the HepG2 cells and up-regulation in the mice are dependent on oxidative stress. The HepG2 cells were exposed to $\mathrm{CoCl}_{2}$ with/without NAC in the absence of serum for $18 \mathrm{~h}$. The mice were treated with $\mathrm{CoCl}_{2}$ with/without $\mathrm{NAC}$ and fasted for $18 \mathrm{~h}$. ROS accumulation in the HepG2 cells was examined by DHE staining (red) (A). Cellular Fgf21 mRNA (B) and secreted FGF21 protein in the media (C) of HepG2 cells were measured by RT-PCR and ELISA, respectively. Plasma FFA (D) and glycerol (E) levels of the mice were measured. The plasma FGF21 level (F) and liver Fgf21 mRNA expression (G) of the mice were measured by ELISA and RT-PCR, respectively. ${ }^{*} \mathrm{P}<0.05$. 


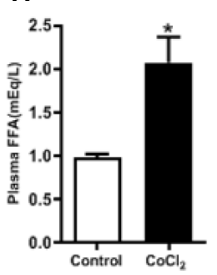

D

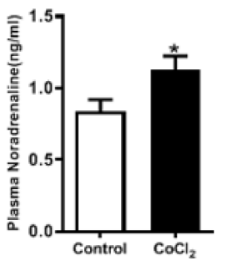

B

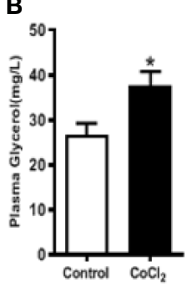

E

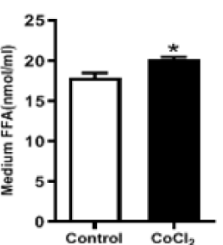

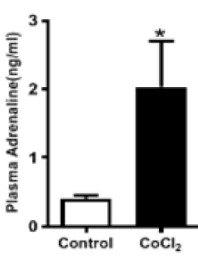

$\mathbf{F}$

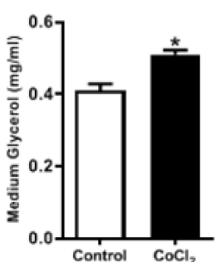

FIGURE 4 | Hypoxia induces adipose lipolysis. The mice were treated with $\mathrm{CoCl}_{2}$ and fasted for $18 \mathrm{~h}$. Plasma FFA (A), glycerol (B), adrenaline (C), and noradrenaline (D) levels were measured by ELISA, respectively. The 3T3-L1 adipocytes were exposed to $\mathrm{CoCl}_{2}$ in the absence of serum for $18 \mathrm{~h}$. Median FFA (E) and glycerol (F) levels were measured by ELISA. * $\mathrm{P}<0.05$.

$0.03 \mathrm{~g})$. To further investigate whether hypoxia-induced adipose lipolysis is via a systemic effect on catecholamine release, the plasma adrenaline and noradrenaline were measured. As shown in Figures 4C, D, the hypoxia treatment significantly increased the plasma level of adrenaline by four folds and moderately increased the level of noradrenaline. Adipose tissue is the main location for excess fat storage and the main source of FFA mobilization during fasting and other metabolic states in which it is needed. We then investigated whether hypoxia increases FFA release from adipocytes. The 3T3L1 adipocytes were treated with $\mathrm{CoCl}_{2}$ for $18 \mathrm{~h}$. This led to an adipocyte lipolysis assessed by FFA and glycerol concentrations in the media (Figures 4E, F). A systemic increase in FFA could stimulate FGF21 expression in the liver through PPAR $\alpha$ activation. Indeed, linoleate-induced FGF21 expression was partially inhibited by a PPAR $\alpha$ antagonist, GW6471, in the HepG2 and H4IIE cells (Supplementary Figure S1).

\section{Fgf21 KO Inhibits Hypoxia-Induced Adipose Tissue Lipolysis}

An important function of FGF21 is to regulate adipose lipolysis. The Fgf $21 \mathrm{KO}$ mice were treated by hypoxia as described above to investigate whether FGF21 plays a role in the lipolysis of adipose tissue under hypoxic conditions. No observable effect was detected on the overall behavior of the mice in response to the $\mathrm{CoCl}_{2}$ treatment when FGF21 was deleted. Surprisingly, the $\mathrm{Fgf} 21 \mathrm{KO}$ mice were found to be resistant to hypoxia-induced adipose lipolysis, as shown by the lack of increase in plasma FFA and glycerol concentrations (Figures 5A, B), indicating that FGF21 plays a critical role in hypoxia-induced adipose lipolysis. Furthermore, hypoxia significantly increased adipose cAMP levels and induced phosphorylation of PKA and HSL in WT mice, but not in the Fgf $21 \mathrm{KO}$ mice (Figures 5C-G), whereas another major enzyme, responsible for TG breakdown in adipose tissue, ATGL, was unchanged (Figures 5H, I). The catecholamine-mediated adrenergic response is an important mechanism in adipose tissue lipolysis (Koppo et al., 2012). The plasma levels of adrenaline and noradrenaline were measured. As shown, hypoxia treatment increased the catecholamine levels in both WT and Fgf21 KO mice (Figures 6A, B). We treated primary adipocytes isolated from the WT and Fgf21 KO mice with synthetic catecholamine, isoproterenol $(1 \mathrm{mmol} / \mathrm{L})$, for $2 \mathrm{~h}$ to determine whether catecholamine-induced adipose lipolysis is mediated by FGF21. The glycerol secreted from the primary adipocytes was significantly increased by isoproterenol treatment in both WT and Fgf21 KO mice (Figure 6C), suggesting that regulation of lipolysis by FGF21 is independent of any catecholamine action.

\section{DISCUSSION}

Previous studies have shown that lipid dysregulation is associated with the tissue hypoxia induced by many pathologic conditions such as cancer (Koizume et al., 2015; Deep and Schlaepfer, 2016), non-alcoholic fatty liver disease (Chen et al., 2019), and cardiovascular disease (Mylonis et al., 2019). FGF21 is a newly described hepatokine that is important in lipid homeostasis. However, the potential link between hypoxiainduced lipolysis and FGF21 expression is not yet investigated. Therefore, we sought to determine how FGF21 is regulated under hypoxic conditions in vivo and in vitro, respectively.

In the present study, we demonstrated that hypoxia increases FGF21 expression in mice (Figures 1A-F). Increased FGF21 expression by hypoxia is not due to the activation of HIF in hepatocytes (Figure 2H), but rather through hypoxia-induced adipose tissue lipolysis (Figures $\mathbf{4 A}, \mathbf{B}$ ), which leads to the mobilization of FFAs and the activation FGF21 synthesis in the liver through PPAR $\alpha$ activation (Supplementary Figure S1). We further demonstrated that FGF21 is required for adipose tissue lipolysis (Figures $\mathbf{5 A - G}$ ).

An important finding of this study is that hypoxia induces a dramatic increase in FGF21 expression in circulation (Figures 1A-C) and hepatic tissue (Figures 1D-F), but not in WAT (Figure 1G). Previous study has demonstrated that circulating FGF21 was mainly produced from liver, as circulating FGF21 level was completely abolished in liverspecific Fgf21 KO mice, but not in adipose-specific Fgf21 KO mice (Markan et al., 2014). It is clear that adipose tissue also expresses FGF21 (Dutchak et al., 2012). However, adiposederived FGF21 acts locally to modulate PPAR $\gamma$ activity in autocrine or paracrine manner involving in the browning of white adipose tissue (Dutchak et al., 2012; Fisher et al., 2012) and is not associated with lipolysis (Arner et al., 2008; Li et al., 2009). Although hepatocytes are a major type of FGF21producing cells, our data showed that the hypoxia-induced FGF21 elevation in the plasma and hepatic tissue is not related to direct exposure of hepatocytes to hypoxia (Figures 2E, F and $\mathbf{3 B}, \mathbf{C})$. It is well-known that hepatic PPAR $\alpha$ activation by 

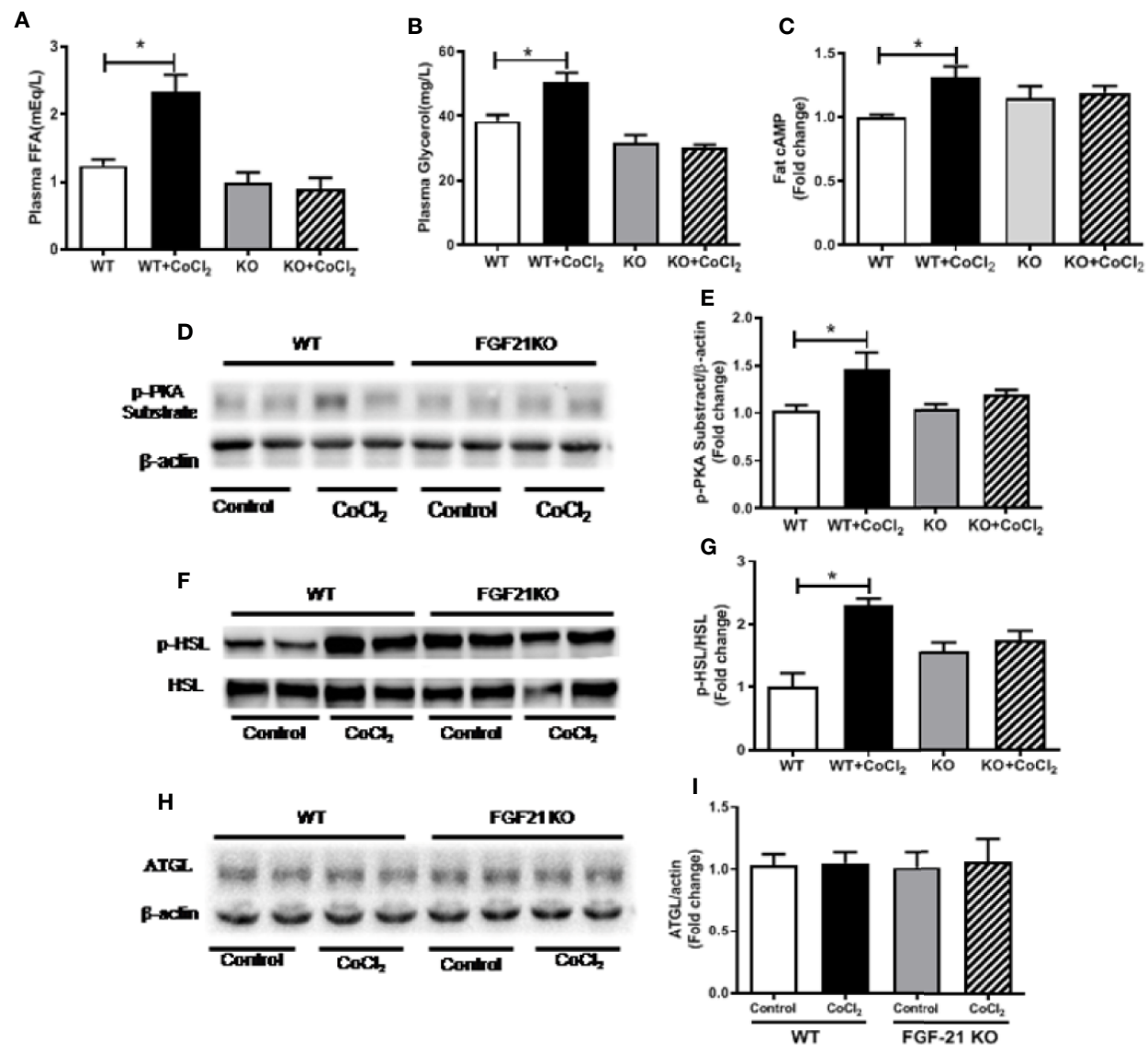

FIGURE 5 | Fgf21 KO inhibits $\mathrm{CoCl}_{2}$-induced adipose tissue lipolysis. WT and Fgf21 $\mathrm{KO}$ mice were treated with $\mathrm{CoCl}$ and fasted for $18 \mathrm{~h}$. Plasma FFA (A) and glycerol (B) levels were measured. Adipose cAMP (C) levels were measured by immunoassay kit. Adipose protein kinase A (PKA) (D-E), p-HSL/HSL (F-G), and adipose triglyceride lipase (ATGL) (H-I) levels were measured by Western blot. *P $<0.05$.
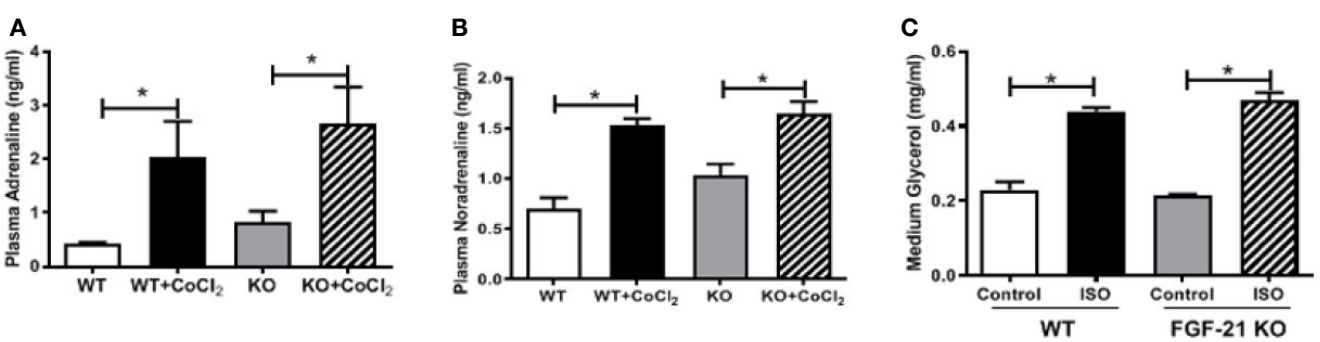

FIGURE 6 | FGF21 regulation of lipolysis is independent of catecholamine action. WT and Fgf21 KO mice were treated with $\mathrm{CoCl}_{2}$ and fasted for $18 \mathrm{~h}$. Plasma adrenaline (A) and noradrenaline (B) levels were measured by ELISA. Primary adipocytes isolated from WT and Fgf21 KO mice were treated with isoproterenol (ISO, $1 \mathrm{mM}$ ) for 2 h. Median glycerol was measured (C). ${ }^{*} \mathrm{P}<0.05$.

FFAs upregulates FGF21 expression (Cuevas-Ramos et al., 2012). Our results showed that hypoxia exposure increased FFA release in 3T3-L1 adipocytes (Figures 4E, F). Therefore, the hypoxia-induced rise in FGF21 expression in circulation and hepatic tissue is likely mediated by increased levels of FFAs from adipose tissue lipolysis.

Adipose tissue lipolysis and adipogenesis are exquisitely controlled processes. It is widely recognized that cAMP 
signaling via PKA is important both in adipogenesis and in lipolysis in WAT (Rogne and Tasken, 2014). In addition to catecholamines, several other non-adrenergic lipolysis factors such as parathyroid hormone (Larsson et al., 2016), cardiac natriuretic peptide (Collins, 2014), thyroid-stimulating hormone (Endo and Kobayashi, 2012), growth hormone (Yip and Goodman, 1999), can also regulate lipolytic process in adipose tissue. On the other hand, insulin signaling pathway, including phosphatidylinositol 3-kinase, phosphoinositidedependent kinase, and protein kinase B (Akt) (Whitman et al., 1988; Stokoe et al., 1997), plays a major role in antilipolytic process (Jensen and Nielsen, 2007). Akt further activates phosphodiesterase $3 \mathrm{~B}$, which mediates degradation of cAMP to 5'-AMP and attenuates PKA-dependent stimulation of lipolysis process (Choi et al., 2006). Our previous study demonstrated that alcohol exposure-induced FGF21 expression stimulated adipose lipolysis through systemic catecholamine reaction (Zhao et al., 2015). Consistent with this finding, our current results showed that hypoxia increased $\beta$-AR-cAMP-PKA-HSL pathway (Figures 5A-G). We also shown in the Figures $4 \mathrm{E}, \mathrm{F}$ that $\mathrm{CoCl}_{2}$ treatment moderately increased media FFA and glycerol concentration in 3T3L1 adipocytes, indicating that the basal lipolysis (independent of catecholamine-induced) was increased by $\mathrm{CoCl}_{2}$. However, the extend of the increase (FFA, 15\%) was much smaller compared to the total lipolysis in animal (including catecholamineinduced) by $\mathrm{CoCl}_{2}$ (FFA 100\%, Figure 4A). These data suggest that $\mathrm{CoCl}_{2}$ induce lipolysis mainly attributes to the systemic activation of catecholamine signaling, which may involves FGF21 activation. Thus, the elevation of FGF21 by hypoxia is a result of hypoxia-induced activation of the adrenergic receptor response, leading to an increase in lipolysis and FFA release in the adipose tissue.

Our results showed that hypoxia-induced FGF21 expression is differentially regulated in intact animals and in hepatocytes (Figures 1A-F, 2E, F). In animals, hypoxia leads to adipose lipolysis, which in turn increases FFA concentration in the circulation, subsequently activating $\operatorname{PPAR} \alpha$ in the liver. However, hypoxia inhibits PPAR $\alpha$ protein expression through HIF- $1 \alpha$ and HIF- $2 \alpha$ accumulation (Narravula and Colgan, 2001). The net effect of the induction of FGF21 by hypoxia is therefore a balance between FFA-induced transcriptional activation and HIF-induced down-regulation of PPAR $\alpha$. By contrast, in vitro hepatocyte culture is not subject to systemic lipolysis, and thus, the HIF-repressed PPAR $\alpha$ contributed to the FGF21 expression. Interestingly, anti-oxidant (NAC) treatment inhibited the changes in FGF21 expression both in vivo (increase) and in vitro (decrease) (Figures 3B-G). NAC has been used widely for its anti-oxidant effect in cell culture and in animal experiments. As shown in our previous study (Liu et al., 2012), NAC itself did not induce changes in FGF21 expression. Our study clearly showed that NAC markedly inhibited $\mathrm{CoCl}_{2}$ suppressed FGF21 expression in $\mathrm{HepG} 2$ cell and $\mathrm{CoCl}_{2}$ increased FGF21 expression in mice, indicating the role of oxidative stress response. Therefore, it is likely that hypoxiainduced oxidative stress is responsible for the decrease in FGF21 expression due to the inactivation of PPARa in hepatocytes, whereas the oxidative stress may increase global catecholamine concentration and enhance adipose tissue lipolysis, subsequently increasing FGF21 expression in animals.

It is well-known that HIF- $\alpha$ regulates the expression of numerous genes in response to hypoxia. However, the hypoxia-responsive element has not yet been found in the promoter region of FGF21. In this study, it was found that inhibition of HIF- $\alpha$ by its specific inhibitor and siRNA, or by genetic deletion of Hif- $1 \alpha$ or Hif- $2 \alpha$, decreased the $\mathrm{CoCl}_{2}$ induced HIF- $\alpha$ protein but did not affect the $\mathrm{CoCl}_{2}$-decreased Fgf21 mRNA level (Figures 2B, C, G, H), indicating that the regulation of FGF21 by hypoxia may be independent of HIF- $\alpha$ transcriptional activity. In summary, our results suggest that HIF is not involved in hypoxia regulation of FGF21 expression in hepatocytes.

What is the physiological significance of the link between hypoxia and FGF21 elevation? The finding that FFA released from adipose tissue mediates hypoxia-induced FGF21 expression may explain the circadian rhythm of FFAs and FGF21 in patients with sleep apnea. In humans, both FFA and FGF21 levels peak at midnight during deep sleep and are at their lowest at noon (Moller et al., 1990; Yu et al., 2011). A recent study has demonstrated that patients with severe sleep apnea exhibit a marked and rapid increase in FFAs compared with control subjects after sleep onset, and that attenuation of the hypoxia via supplementation of oxygen normalizes the FFA profile (Jun et al., 2011). This strongly suggests that hypoxia may account for the FFA release in patients with sleep disorders. However, the nocturnal rise of FGF21 is secondary to the midnight increase of FFA in humans. Thus, the hypoxia status caused by severe sleep apnea after sleep onset results in an increase of circulating FFA, which may contribute to the nocturnal rise in FGF21. The hypoxia-induced increase of FFAs and glycerol in the blood (Figures 5A, B) and cAMP-PKA-HSL pathway in the adipose tissue were completely blocked (Figures 5C-G) in Fgf $21 \mathrm{KO}$ mice, evidently suggesting that FGF21 is required for hypoxiainduced lipolysis. However, it seems that endogenous FGF21 is barely involved in catecholamine-induced adipocyte lipolysis since $\mathrm{Fg} f 21 \mathrm{KO}$ mice have similar responses to isoproterenol for lipolysis compared with WT mice.

The role of endogenous FGF21 favoring lipolysis in adipose tissue under hypoxic insult may explain the rise in circulating FFA levels in obese subjects. Obesity induces a hypoxic state in adipocytes. In addition to inflammation, hypoxia enhances adipocyte lipolysis, and releases lipolytic products including FFAs, which in turn enhance hepatic FGF21 production through the activation of PPAR $\alpha$. This feed forward effect increases obesityinduced circulating FFA concentration, leading to insulin resistance. By contrast, FGF21 reduces hormone-induced lipolysis through a negative feedback loop (Chen et al., 2011). The differential feedback regulation of adipocyte lipolysis by FGF21 in differing metabolic states may be indicative of a complex fine-tuning mechanism in lipid homeostasis. The regulation of lipolytic activity by FGF21 under distinct physiological and pathological conditions thus remains to be clarified. 
In summary, the present study demonstrated that hypoxia induces adipocyte lipolysis leading to an increased FGF21 expression in mice. Hypoxia stimulates adipocyte lipolysis by oxidative stress-mediated elevation in the catecholamine response and enhances HSL phosphorylation; this process requires FGF21. The positive feedback regulation mechanism between FGF21 and adipocyte lipolysis in hypoxia indicates that FGF21 regulates lipolysis in response to varying metabolic states. As an adaptive response to hypoxia, HIF- $\alpha$ protein is increased in the liver but is not possibly involved in the hepatic expression of FGF21. These findings provide new insight into the molecular mechanism underlying the regulation of FGF21 under hypoxic conditions.

\section{DATA AVAILABILITY STATEMENT}

The raw data supporting the conclusions of this article will be made available by the authors, without undue reservation, to any qualified researcher.

\section{ETHICS STATEMENT}

The animal study was reviewed and approved by the Institutional Animal Care and Use Committee of Chongqing University Three Gorges Hospital.

\section{REFERENCES}

Arner, P., Pettersson, A., Mitchell, P. J., Dunbar, J. D., Kharitonenkov, A., and Ryden, M. (2008). FGF21 attenuates lipolysis in human adipocytes - a possible link to improved insulin sensitivity. FEBS Lett. 582 (12), 1725-1730. doi: 10.1016/j.febslet.2008.04.038

Barb, D., Bril, F., Kalavalapalli, S., and Cusi, K. (2019). Plasma Fibroblast Growth Factor 21 Is Associated With Severity of Nonalcoholic Steatohepatitis in Patients With Obesity and Type 2 Diabetes. J. Clin. Endocrinol. Metab. 104 (8), 3327-3336. doi: 10.1210/jc.2018-02414

Beenken, A., and Mohammadi, M. (2009). The FGF family: biology, pathophysiology and therapy. Nat. Rev. Drug Discovery 8 (3), 235-253. doi: $10.1038 / \mathrm{nrd} 2792$

Cai, G., Liu, J., Wang, M., Su, L., Cai, M., Huang, K., et al. (2019). Mutual promotion of FGF21 and PPARgamma attenuates hypoxia-induced pulmonary hypertension. Exp. Biol. Med. (Maywood) 244 (3), 252-261. doi: 10.1177/1535370219828692

Chen, W., Hoo, R. L., Konishi, M., Itoh, N., Lee, P. C., Ye, H. Y., et al. (2011). Growth hormone induces hepatic production of fibroblast growth factor 21 through a mechanism dependent on lipolysis in adipocytes. J. Biol. Chem. 286 (40), 34559-34566. doi: 10.1074/jbc.M111.285965

Chen, J., Chen, J., Huang, J., Li, Z., Gong, Y., Zou, B., et al. (2019). HIF-2alpha upregulation mediated by hypoxia promotes NAFLD-HCC progression by activating lipid synthesis via the PI3K-AKT-mTOR pathway. Aging (Albany N.Y.) 11 (23), 10839-10860. doi: 10.18632/aging.102488

Choi, Y. H., Park, S., Hockman, S., Zmuda-Trzebiatowska, E., Svennelid, F., Haluzik, M., et al. (2006). Alterations in regulation of energy homeostasis in cyclic nucleotide phosphodiesterase 3B-null mice. J. Clin. Invest. 116 (12), 3240-3251. doi: 10.1172/JCI24867

Collins, S. (2014). A heart-adipose tissue connection in the regulation of energy metabolism. Nat. Rev. Endocrinol. 10 (3), 157-163. doi: 10.1038/nrendo. 2013.234

\section{AUTHOR CONTRIBUTIONS}

GW, YL, and CT designed the study and wrote the manuscript, GW and YL performed the experiments, analyzed, and interpreted the data. WF contributed to the critical discussion and manuscript revision. XA and WL assisted in the completion of the project. All authors contributed to the article and approved the submitted version.

\section{FUNDING}

This work was supported by National Natural Science Foundation of China (81873571, 81300311), Chongqing Natural Science Foundation (cstc2019jcyj-msxmX0774), Projects of Medical and Health Technology Program in Zhejiang Province (2015KYB234, 2017KY720), and Wenzhou Science and Technology Bureau Foundation (ZS2017016, Y20140739, Y20150094).

\section{SUPPLEMENTARY MATERIAL}

The Supplementary Material for this article can be found online at: https://www.frontiersin.org/articles/10.3389/fphar.2020.01279/ full\#supplementary-material

SUPPLEMENTARY FIGURE 1 | FFA-induced FGF21 up-regulation is mediated by PPAR $\alpha$. HepG2 (A) and H4IIE (B) cells were treated with linoleate (150 $\mu \mathrm{mol} / \mathrm{L})$ and a PPAR $\alpha$ antagonist, GW6471 (100 nmol/L), for 24 hours. Cellular Fgf21 mRNA levels were measured by RT-PCR. * $\mathrm{P}<0.05$.

Cuevas-Ramos, D., Aguilar-Salinas, C. A., and Gomez-Perez, F. J. (2012). Metabolic actions of fibroblast growth factor 21. Curr. Opin. Pediatr. 24 (4), 523-529. doi: 10.1097/MOP.0b013e3283557d22

Deep, G., and Schlaepfer, I. R. (2016). Aberrant Lipid Metabolism Promotes Prostate Cancer: Role in Cell Survival under Hypoxia and Extracellular Vesicles Biogenesis. Int. J. Mol. Sci. 17 (7), 1061. doi: 10.3390/ijms17071061

Degirolamo, C., Sabba, C., and Moschetta, A. (2016). Therapeutic potential of the endocrine fibroblast growth factors FGF19, FGF21 and FGF23. Nat. Rev. Drug Discov. 15 (1), 51-69. doi: 10.1038/nrd.2015.9

Ding, X., Boney-Montoya, J., Owen, B. M., Bookout, A. L., Coate, K. C., Mangelsdorf, D. J., et al. (2012). betaKlotho is required for fibroblast growth factor 21 effects on growth and metabolism. Cell Metab. 16 (3), 387-393. doi: 10.1016/j.cmet.2012.08.002

Dushay, J., Chui, P. C., Gopalakrishnan, G. S., Varela-Rey, M., Crawley, M., Fisher, F. M., et al. (2010). Increased fibroblast growth factor 21 in obesity and nonalcoholic fatty liver disease. Gastroenterology 139 (2), 456-463. doi: 10.1053/j.gastro.2010.04.054

Dutchak, P. A., Katafuchi, T., Bookout, A. L., Choi, J. H., Yu, R. T., Mangelsdorf, D. J., et al. (2012). Fibroblast growth factor-21 regulates PPARgamma activity and the antidiabetic actions of thiazolidinediones. Cell 148 (3), 556-567. doi: $10.1016 /$ j.cell.2011.11.062

Endo, T., and Kobayashi, T. (2012). Expression of functional TSH receptor in white adipose tissues of hyt/hyt mice induces lipolysis in vivo. Am. J. Physiol. Endocrinol. Metab. 302 (12), E1569-E1575. doi: 10.1152/ajpendo.00572.2011

Famulla, S., Schlich, R., Sell, H., and Eckel, J. (2012). Differentiation of human adipocytes at physiological oxygen levels results in increased adiponectin secretion and isoproterenol-stimulated lipolysis. Adipocyte 1 (3), 132-181. doi: 10.4161/adip.19962

Fisher, F. M., Kleiner, S., Douris, N., Fox, E. C., Mepani, R. J., Verdeguer, F., et al. (2012). FGF21 regulates PGC-1alpha and browning of white adipose tissues in adaptive thermogenesis. Genes Dev. 26 (3), 271-281. doi: 10.1101/ gad.177857.111 
Fon Tacer, K., Bookout, A. L., Ding, X., Kurosu, H., John, G. B., Wang, L., et al. (2010). Research resource: Comprehensive expression atlas of the fibroblast growth factor system in adult mouse. Mol. Endocrinol. 24 (10), 2050-2064. doi: 10.1210/me.2010-0142

Jensen, M. D., and Nielsen, S. (2007). Insulin dose response analysis of free fatty acid kinetics. Metabolism 56 (1), 68-76. doi: 10.1016/j.metabol.2006.08.022

Jun, J. C., Drager, L. F., Najjar, S. S., Gottlieb, S. S., Brown, C. D., Smith, P. L., et al. (2011). Effects of sleep apnea on nocturnal free fatty acids in subjects with heart failure. Sleep 34 (9), 1207-1213. doi: 10.5665/SLEEP.1240

Kim, S. H., Kim, K. H., Kim, H. K., Kim, M. J., Back, S. H., Konishi, M., et al. (2015). Fibroblast growth factor 21 participates in adaptation to endoplasmic reticulum stress and attenuates obesity-induced hepatic metabolic stress. Diabetologia 58 (4), 809-818. doi: 10.1007/s00125-014-3475-6

Kliewer, S. A., and Mangelsdorf, D. J. (2019). A Dozen Years of Discovery: Insights into the Physiology and Pharmacology of FGF21. Cell Metab. 29 (2), 246-253. doi: 10.1016/j.cmet.2019.01.004

Koizume, S., Ito, S., Nakamura, Y., Yoshihara, M., Furuya, M., Yamada, R., et al. (2015). Lipid starvation and hypoxia synergistically activate ICAM1 and multiple genes in an Spl-dependent manner to promote the growth of ovarian cancer. Mol. Cancer 14 (77), 1-15. doi: 10.1186/s12943-015-0351-Z

Koppo, K., Siklova-Vitkova, M., Klimcakova, E., Polak, J., Marques, M. A., Berlan, M., et al. (2012). Catecholamine and insulin control of lipolysis in subcutaneous adipose tissue during long-term diet-induced weight loss in obese women. Am. J. Physiol. Endocrinol. Metab. 302 (2), E226-E232. doi: 10.1152/ajpendo.00240.2011

Larsson, S., Jones, H. A., Goransson, O., Degerman, E., and Holm, C. (2016). Parathyroid hormone induces adipocyte lipolysis via PKA-mediated phosphorylation of hormone-sensitive lipase. Cell Signal 28 (3), 204-213. doi: 10.1016/j.cellsig.2015.12.012

Lewis, J. E., Ebling, F. J. P., Samms, R. J., and Tsintzas, K. (2019). Going Back to the Biology of FGF21: New Insights. Trends Endocrinol. Metab. 30 (8), 491-504. doi: $10.1016 /$ j.tem.2019.05.007

Li, X., Ge, H., Weiszmann, J., Hecht, R., Li, Y. S., Veniant, M. M., et al. (2009). Inhibition of lipolysis may contribute to the acute regulation of plasma FFA and glucose by FGF21 in ob/ob mice. FEBS Lett. 583 (19), 3230-3234. doi: 10.1016/j.febslet.2009.09.012

Liu, Y., Wang, C., Wang, Y., Ma, Z., Xiao, J., McClain, C., et al. (2012). Cobalt chloride decreases fibroblast growth factor-21 expression dependent on oxidative stress but not hypoxia-inducible factor in Caco-2 cells. Toxicol. Appl. Pharmacol. 264 (2), 212-221. doi: 10.1016/j.taap.2012.08.003

Mahat, B., Chasse, E., Mauger, J. F., and Imbeault, P. (2016). Effects of acute hypoxia on human adipose tissue lipoprotein lipase activity and lipolysis. $J$. Transl. Med. 14 (1), 212. doi: 10.1186/s12967-016-0965-y

Markan, K. R., Naber, M. C., Ameka, M. K., Anderegg, M. D., Mangelsdorf, D. J., Kliewer, S. A., et al. (2014). Circulating FGF21 is liver derived and enhances glucose uptake during refeeding and overfeeding. Diabetes 63 (12), 4057-4063. doi: 10.2337/db14-0595

Menrad, H., Werno, C., Schmid, T., Copanaki, E., Deller, T., Dehne, N., et al. (2010). Roles of hypoxia-inducible factor-1alpha (HIF-1alpha) versus HIF2alpha in the survival of hepatocellular tumor spheroids. Hepatology 51 (6), 2183-2192. doi: 10.1002/hep.23597

Moller, N., Jorgensen, J. O., Schmitz, O., Moller, J., Christiansen, J., Alberti, K. G., et al. (1990). Effects of a growth hormone pulse on total and forearm substrate fluxes in humans. Am. J. Physiol. 258 (1 Pt 1), E86-E91. doi: 10.1152/ ajpendo.1990.258.1.E86

Mylonis, I., Simos, G., and Paraskeva, E. (2019). Hypoxia-Inducible Factors and the Regulation of Lipid Metabolism. Cells 8 (3), 214. doi: 10.3390/cells8030214

Narravula, S., and Colgan, S. P. (2001). Hypoxia-inducible factor 1-mediated inhibition of peroxisome proliferator-activated receptor alpha expression during hypoxia. J. Immunol. 166 (12), 7543-7548. doi: 10.4049/jimmunol. 166.12.7543
Plihalova, A., Bartakova, H., Vasakova, M., Gulati, S., deGlisezinski, I., Stich, V., et al. (2016). The effect of hypoxia and re-oxygenation on adipose tissue lipolysis in COPD patients. Eur. Respir. J. 48 (4), 1218-1220. doi: 10.1183/ 13993003.00602-2016

Potthoff, M. J., Inagaki, T., Satapati, S., Ding, X., He, T., Goetz, R., et al. (2009). FGF21 induces PGC-1alpha and regulates carbohydrate and fatty acid metabolism during the adaptive starvation response. Proc. Natl. Acad. Sci. U. S. A. 106 (26), 10853-10858. doi: 10.1073/pnas.0904187106

Rogne, M., and Tasken, K. (2014). Compartmentalization of cAMP signaling in adipogenesis, lipogenesis, and lipolysis. Horm. Metab. Res. 46 (12), 833-840. doi: 10.1055/s-0034-1389955

Siques, P., Brito, J., and Pena, E. (2018). Reactive Oxygen Species and Pulmonary Vasculature During Hypobaric Hypoxia. Front. Physiol. 9, 865. doi: 10.3389/ fphys.2018.00865

Stokoe, D., Stephens, L. R., Copeland, T., Gaffney, P. R., Reese, C. B., Painter, G. F., et al. (1997). Dual role of phosphatidylinositol-3,4,5-trisphosphate in the activation of protein kinase B. Science 277 (5325), 567-570. doi: 10.1126/ science.277.5325.567

Wang, H. W., Jiang, X., Zhang, Y., Wang, J., Xie, J., Wang, Y. Q., et al. (2019). FGF21 Protects Against Hypoxia Injury Through Inducing HSP72 in Cerebral Microvascular Endothelial Cells. Front. Pharmacol. 10, 101. doi: 10.3389/ fphar.2019.00101

Whitman, M., Downes, C. P., Keeler, M., Keller, T., and Cantley, L. (1988). Type I phosphatidylinositol kinase makes a novel inositol phospholipid, phosphatidylinositol-3-phosphate. Nature 332 (6165), 644-646. doi: 10.1038/ $332644 \mathrm{a} 0$

Yin, J., Gao, Z., He, Q., Zhou, D., Guo, Z., and Ye, J. (2009). Role of hypoxia in obesity-induced disorders of glucose and lipid metabolism in adipose tissue. Am. J. Physiol. Endocrinol. Metab. 296 (2), E333-E342. doi: 10.1152/ ajpendo.90760.2008

Yip, R. G., and Goodman, H. M. (1999). Growth hormone and dexamethasone stimulate lipolysis and activate adenylyl cyclase in rat adipocytes by selectively shifting Gi alpha2 to lower density membrane fractions. Endocrinology 140 (3), 1219-1227. doi: 10.1210/endo.140.3.6580

Yu, H., Xia, F., Lam, K. S., Wang, Y., Bao, Y., Zhang, J., et al. (2011). Circadian rhythm of circulating fibroblast growth factor 21 is related to diurnal changes in fatty acids in humans. Clin. Chem. 57 (5), 691-700. doi: 10.1373/ clinchem.2010.155184

Yu, W., Wang, X., Ni, Y., Huai, D., Hao, H., Li, Q., et al. (2019). Association of OSAHS Hypoxia Indicators with Early Renal Injury and Serum Fibroblast Growth Factor 21 in Obese Type 2 Diabetic Patients. Diabetes Ther. 10 (4), 1357-1368. doi: 10.1007/s13300-019-0639-x

Zhang, X., Saarinen, A. M., Hitosugi, T., Wang, Z., Wang, L., Ho, T. H., et al. (2017). Inhibition of intracellular lipolysis promotes human cancer cell adaptation to hypoxia. Elife 6 (10), e31132. doi: 10.7554/eLife.31132

Zhao, C., Liu, Y., Xiao, J., Liu, L., Chen, S., Mohammadi, M., et al. (2015). FGF21 mediates alcohol-induced adipose tissue lipolysis by activation of systemic release of catecholamine in mice. J. Lipid Res. 56 (8), 1481-1491. doi: 10.1194/ jlr.M058610

Conflict of Interest: The authors declare that the research was conducted in the absence of any commercial or financial relationships that could be construed as a potential conflict of interest.

Copyright (c) $2020 \mathrm{Wu}$, Liu, Feng, An, Lin and Tang. This is an open-access article distributed under the terms of the Creative Commons Attribution License (CC BY). The use, distribution or reproduction in other forums is permitted, provided the original author(s) and the copyright owner(s) are credited and that the original publication in this journal is cited, in accordance with accepted academic practice. No use, distribution or reproduction is permitted which does not comply with these terms. 